\title{
Conflicting Models of Care for People with Mental Disabilities in Charles Dickens's Fiction and Journalism
}

Gillian Ray-Barruel

Griffith University

In contrast to the mid-Victorian medical discourse extolling the benefits of asylums and residential training schools for children with mental impairments, contemporary literary representations criticize the institutional provision of care, instead favoring a community solution, which indeed was the predominant model throughout the Victorian era. The article explores representations of caring in Charles Dickens's novels and journalism in comparison to the models of care available for people with mental disabilities in England at the time. Dickens's support for the disadvantaged is legendary, but the subject of care for people with mental disabilities in his work is more nuanced than has hitherto been shown.

\section{Introduction}

Charles Dickens's interest in disability is demonstrated by the many characters with impairments in his fiction, as well as several journal articles regarding the care of people with mental disabilities. Despite his support for reforms for the disadvantaged of all stripes, Dickens’s fiction presents a very different approach to caring for people with mental impairments than that advocated in his non-fiction. Why he opposes asylums in his novels but 
supports them in his non-fiction has not been satisfactorily addressed. In this article, I explore models of caring in Dickens's fiction and non-fiction and suggest possible explanations for these discrepancies.

\section{Disability in Victorian literature}

With his sharp eye for the outrageous and his love of the bizarre, Dickens included characters with mental impairments in several of his novels, including Pickwick Papers (1837), Nicholas Nickleby (1838-39), Barnaby Rudge (1841), David Copperfield (1849-50), and Little Dorrit (1855-57). With the exception of Little Dorrit, all were published before Dickens visited the Earlswood Asylum in 1853. His fascination for the anomalous mind and body has led many to question, what did Dickens know about illness and impairment? How much he knew about mental disability in his early career is unclear. As a parliamentary reporter in the 1830s he would have been aware of the contemporary discussions about so-called lunatic asylum reforms, although there is no evidence that he wrote about them. The Lockean concept of lunacy $^{1}$ as a temporary derangement of reason and idiocy as an untreatable malady from birth persisted until the 1840s, so this was the predominant medical and cultural viewpoint when he began writing. A turning point in the treatment of people with mental impairments came in the 1850s, a change captured in several articles he published.

\footnotetext{
${ }^{1}$ The terms used in this article to describe intellectual and mental impairment are the original terms used at the time. While many of these are now considered offensive, disability scholars agree that using the terms as they arose in history is the best way to convey the changing nature of understanding intellectual impairment. No offence is intended by the author in using these archaic terms.
} 
Dickens has been esteemed for his seemingly accurate portrayals of medical conditions that did not exist in the medical literature at the time he was writing. Neurologist Russell Brain said of Dickens that he "looked on disease with the observing eye of the expert clinician” (124). Dickens’s percipience in capturing physical and mental anomalies is indeed remarkable for someone with no medical training. This astute perception is possibly due to his early training as a journalist, but Dickens was foremost a novelist. He could describe conditions remarkably well, but he also changed symptoms to suit his plots, so his characters cannot be taken as accurate portrayals of disability. In his landmark book, Idiocy, Patrick McDonagh cautions that fictional portrayals of idiocy cannot necessarily reveal how people considered idiotic or imbecile were treated, but they do reveal prevailing stereotypes and cultural concerns, and can show the symbolic function of disability in society. Dickens's work is extremely useful in this respect.

Although Dickens was a prolific author, creating legions of characters with all kinds of impairments, he was certainly not the only Victorian to be intrigued with the atypical body. Disability is a recurrent theme in Victorian literature, reflecting the everyday reality of an era in which sanitation and nutrition were inadequate, effective anesthesia, antibiotics, and many vaccines had yet to be discovered, and occupational safety measures did not exist. Meanwhile, the worth of an individual was measured in terms of productive capacity, and political debates about the economic and social merit of the working-class fuelled fears of the decline of British supremacy. Martha Stoddard Holmes proposes interpreting disability as a defining feature of Victorian anxiety about culture. Her research confirms that melodramatic portrayals of disability mimic and manipulate middle-class values and concerns. For instance, disabled women in fiction do not marry, or if they marry, do not bear children. If characters with presumed hereditary taints—such as intemperance, deviant sexuality, or physical or mental disability—unite, their offspring are usually condemned to ill health and early death. These 
literary tropes echo the “Victorian medical science’s concern about the transmission of physical illness and impairment” (Holmes 7). The formative power of written materials, including novels, periodicals and newspapers, to impart middle-class values was well recognized by the Victorians, and producing counter narratives to popular stereotypes of disability was extraordinarily difficult, as authors knew their work would not be published if it contravened accepted standards of morality.

Representations of mental disabilities in fiction changed during the nineteenth century as the medical influence became more dominant, although Hilary Dickinson argues that literary representations often do not support the prevailing medical view of idiocy. For example, optimism for so-called idiot asylums reached its zenith in the mid-nineteenth century, yet this is conspicuously absent from the fiction of the period. While doctors and social reformers were enthusiastic about asylums, novelists were apparently less so. Idiot asylums do not appear in Victorian novels, despite wrongful confinement in private lunatic asylums being a popular theme. Real-life cases of wrongful confinement in asylums were also reported, and sensation novelists Wilkie Collins, Charles Reade, and Mary Elizabeth Braddon played on this public fear. While novelists drew upon current medical themes to some extent, the exploration of mental disability in fiction did not simply reflect prevailing medical attitudes but rather sought to fashion a new middle-class moral consciousness. Mental impairments feature in Victorian fiction largely as catalysts for middle-class action, rather than as attempts to portray existing conditions: “disabled people function almost exclusively as a lesson for the nondisabled, promoting behaviours such as patience, cheerfulness, and 'making the best of things'” (Snyder and Mitchell 46). A picture emerges of disability in the Victorian era as a cultural symbol with religious and moral significance. 


\section{Commodification of the body in the Industrial era}

Bodies are "given social significance within particular societies” (36), claims Brendan Gleeson, depending on the social roles and responsibilities they can perform. Concern over productive and non-productive bodies began with the Industrial Revolution and intensified throughout the nineteenth century. Attitudes to poor and disabled people deteriorated with the publication of Thomas Malthus's Essay on the Principles of Population (1798), which argued that charity exacerbated poverty by increasing the population without increasing the food supply. Gradually the belief grew among the middle classes that charity fostered dependency and should not be encouraged. Dickens, however, vehemently rejected this position throughout his life. His impecunious upbringing and New Testament sensibilities led to his favorable regard for the poor and downtrodden, both in his writing and in everyday life, even to the point of establishing Urania Cottage, a home for "fallen" women, the management of which he personally oversaw for many years.

Nineteenth-century discourse is permeated with debates about political economy meshed with the concurrent fascination with science, creating a link between human biology and economic value. The physical body became a commodity, able to exchange labor for goods and services. The healthy poor were seen as valuable, as they would toil for long hours and minimum wages, thus enabling economic growth. The sick and disabled poor, unable to compete in the grim labor market, began to be viewed as an "encumbrance” who did "nothing but consume what society produced” (Foucault 411). The incurability of most impairments meant that debilitation equaled disqualification from the workforce and a descent into poverty and decrepitude for many.

In order to ensure relief was only accessed by the “deserving” poor, the Poor Law Amendment Act of 1834 introduced the workhouse test. As a parliamentary reporter, Dickens 
would have heard the raging debates about workhouses, a theme he put to use in Oliver Twist. Workhouse conditions were grim, being “designed to deter "less eligible” by the diet provided, the drudging work required, [and] the separation of families imposed” (Cornish and Clark 533). The aged, “idiotic,” and infirm were admitted to the workhouse only if they lacked other means of support. According to this Act "any dangerous Lunatic, insane person, or Idiot should not be detained in a workhouse for longer than fourteen days but removed to an insane asylum” (Murphy 54), but this policy was not routinely implemented. Decisions to relocate a pauper lunatic from the workhouse to the asylum depended on several factors, including "Poor Law finances and politics, the preferences of the magistrates, Guardians and Union personnel, as well as a complex pattern of negotiations with families and friends of those potentially or actually identified as pauper lunatics” (Adair et al. 3). Not surprisingly, fear of the workhouse and the lunatic asylum is a common theme in many Victorian novels, including those of Dickens.

\section{Paternalism in Nicholas Nickleby and Barnaby Rudge}

In contrast to the laissez-faire economics and Malthusian principles of his own era, Dickens's fiction reflects eighteenth-century moral values such as community kinship and benevolence toward the less fortunate. In the early modern era, a complex system of community relief, parish relief, family care, and institutional care had provided for the most needy (Rushton). The parliamentary Act for the Relief of the Poor 1601, popularly known as the Elizabethan Poor Law, established a formal practice of poor relief in England and Wales. Under this law, responsibility for the person with a disability was shared between family and community. If the family could not support its members, due to ill health, disablement of the main 
breadwinner, or poverty, responsibility fell to the local parish to provide essential aid, including boarding out an idiot or imbecile member to a substitute caregiver or distant relative for a small fee (Andrews).

In his fiction Dickens hearkens back to traditional, pre-industrial models of caring for those with mental disabilities. Rather than being sequestered in an asylum, his characters with mental disorders are cared for in the community. In the pre-industrial era, the slower work style and supportive network of large families and neighbors enabled a person with a disability to participate in community life in a way that became impossible with industrialization and urbanization (Mahendra). Mass migration to manufacturing towns, long hours of demanding factory work, and squalid, overcrowded living conditions brought about profound changes in the lives of the populace. Town families with an idiot child or adult undoubtedly felt the repercussions of reduced family and community support; in rural communities the exodus of skilled people to the towns saw an increase in the ratio of people with mental disabilities, making them both more apparent and more problematic due to reduced available support (Mahendra). If the primary caregiver died, accommodation and care for idiots often was provided by widows or women with large families who could use the added income. Although domestic care remained the preferred means of care for both lunatics and idiots, many lunatics were adults without relatives to care for them, so institutionalization was more likely in this population (Rushton). Asylums at this time did not accept idiots, believing idiocy was incurable.

Responding to the bitter circumstances of poor and disabled people, Dickens sought to create portrayals that would elicit sympathy among his middle-class readers, many of whom shared his paternalistic belief that caring for people with disabilities was a Christian duty. Gerald Dworkin describes paternalism as “the interference with a person’s liberty of action justified by reasons referring exclusively to the welfare, good, happiness, needs, interests or 
values of the person being coerced” (65). A paternalistic perspective might assume that the non-disabled person knows what is best for the person with a disability. In Dickens's fiction, the idiot figure is usually harmless, benevolent and socially included, but he or she needs guidance, and this is a community responsibility. Dickens’s benevolent characters are rewarded with happiness and good fortune, while the destiny of misers and the unscrupulous is certain to be dismal. In this way, Dickens supports altruism by showing the good that comes of it, both for the philanthropist and those who are helped. Laura Otis claims that Dickens openly “hoped to stimulate social reform through his fiction” (445), but Amanda Claybaugh argues that Dickens only realized the power of novels to create social reform after the publication of Nicholas Nickleby led to a public outcry about the conditions in Yorkshire schools, resulting in the closure of many.

Certainly, Dickens’s depictions of helpless children, people with disabilities, and the distressed working class were crafted to inspire pity among middle classes, performing the role of what David Mitchell and Sharon Snyder call a "narrative prosthesis.” Dickens’s idiot characters are child-like and inaccurate representations of mental impairment, but for the Victorian reader, their simplicity provided a refreshing contrast to his conniving and meanspirited characters. From a twenty-first century perspective, this is problematic because unrealistic representations can skew the reader's understanding of disability. Mark Priestley cautions that cultural constructions of disabled people as "childlike [...] innocent, asexual, or untamed” echo medico-legal perspectives that regard people with disabilities as unable to make independent decisions, requiring formal power relationships to provide "custodial care and surveillance” (97). This is especially evident in Dickens's fiction. Each of the mentally disabled characters considered in this article needs someone to assume responsibility for his safety and welfare. 
The characters of Smike (Nicholas Nickleby), Barnaby (Barnaby Rudge), and Mr Dick (David Copperfield) are all boys trapped in a man's body. Although each is shown to work and contribute to the family economy, thus becoming accepted members of the community, they nevertheless need a strong, middle-class hero or heroine to act for them. In Nicholas Nickleby, Nicholas befriends the simple-minded Smike, mentally disabled by cruelty and neglect. In Yorkshire, Smike "could milk a cow and groom a horse with anybody" (279); at Portsmouth, the Crummles claim Smike is "cut out” (287) for performing on stage; and in London, he makes "the garden a perfect wonder to look upon" (456). Notwithstanding his efforts and obvious talents, Smike is treated as a child, and his gardening is downplayed as a pastime, despite his providing food for the family table. Barnaby likewise contributes to the family economy by gardening and straw plaiting, and having his raven perform for donations, but these activities are outweighed in the text by the concentration on his being "silly" (94). Such representations support Timothy Stainton's assertion that this period should not be seen as a "golden age” because people with mental impairments were often marginalized in the community. Only Mr Dick’s contributions have undisputed value, as I discuss.

In Victorian fiction, characters with disabilities either die or are otherwise normalized by the plot (Holmes). Despite Nicholas's desire to help Smike, the hapless lad is doomed to die because he realizes that his love for the beautiful Kate Nickleby will be forever in vain. Dickens’s message is clear: Smike is a suitable object of charity and pity, but no beautiful woman would ever fall in love with him. Mistreatment of the idiotic and infirm is abhorrent to Dickens, as shown by his numerous examples of cruel characters being punished, but he cannot imagine those with disabilities as worthy of love and marriage. Also, controversial disability portrayals would likely not have been published, and as a successful and wealthy novelist Dickens was forever alert to the sensibilities of his reading public. 
Barnaby does not die, but he is normalized by becoming more rational, an inconceivable outcome for idiots at the time. This unlikely improvement in Barnaby's mental state has intrigued critics. When Dickens initially conceived of writing Barnaby Rudge in the late 1830s, idiocy was still thought to be a permanent incapacity. The change in Barnaby has been attributed to the care he receives in the new Maypole community. David Oberhelman claims that Barnaby’s “responsiveness to the 'therapy’ he receives before and after the riots” enables him "by the end of the novel to restore some control over his wild impulses, mainly because he is subjected to what can figuratively be termed a regimen of moral rather than coercive treatment” (40). McDonagh claims that by applying moral principles to Barnaby, Dickens "foreshadows the philanthropic asylum movement that began toward the end of the 1840s, with the goal of educating and returning to the community people labelled as 'idiots'” (“Only an Almost,” 68).

The attribution of Barnaby’s improvement to moral treatment is an inadequate explanation, as I explain, but first a short synopsis of moral treatment is in order. From the late eighteenth century, lunacy reforms began to sweep across England and France, and innovations such as the removal of chains from mental patients in Paris and the implementation of moral treatment at the York Retreat, a private lunatic asylum in the north of England, gained wide publicity. Murray Simpson insists that moral treatment was not based solely, or even primarily, on humanitarian concerns; rather, it focused on adapting an inmate's behavior to the environment by self-discipline and a spirit of utilitarianism. By the 1840s, moral treatment had begun to be instituted in the large English lunatic asylums, particularly by Dr John Conolly, the superintendent of the Middlesex County Lunatic Asylum at Hanwell (1839-1843) and later one of the founders of the Earlswood Asylum for Idiots. Under Conolly’s supervision, the Hanwell asylum became famous for its non-restraint methods. How much Dickens knew about moral treatment at this time is unclear. Although he 
would have read about asylum reforms, there is no evidence that he visited the Hanwell asylum and he did not meet Conolly until 1850.

Interpreting moral treatment as responsible for Barnaby's improved mental state is problematic for three reasons. First, it suggests that Dickens saw Barnaby as a lunatic, rather than an idiot, despite the novel repeatedly labelling him as the latter, because moral treatment was only applied to lunatics, not idiots, in 1841 when the book was written. Second, it implies that Dickens had the foresight to use moral treatment for idiots before this was even considered feasible, a highly improbable scenario. Third, during their self-imposed five-year exile before the riots, his mother already provides a happy environment for Barnaby, keeping him close to her and occupied with work, but this home, being penurious and overshadowed by fear, is incapable of tethering Barnaby or of tempering his enthusiasm for the riches Stagg promises him.

Advocates of moral treatment saw it as a form of disciplinary conditioning for people with mental disability, designed to teach self-control and curb impulsive behaviour. This in turn was expected to teach people to become economically productive. Dickens criticized the harsher precepts of political economy, but he did believe in the value of work, and notably all his mentally disabled characters are shown working. Dickens, however, viewed work as beneficial less for its economic benefits than because it enabled a person to make a useful community contribution. For Dickens, community is all-important, and nothing can take the place of "human warmth” (“On Strike,” 558). Rather than seeing the Maypole community as an illustration of the beneficial effects of moral treatment on the intellectual capacity of idiots, it is more plausible that Dickens created this idyllic community with the benevolent Gabriel Varden providing a comfortable working and living environment for poor and disabled people—a recurrent theme in Dickens's fiction—as a representation of Dickens's own beliefs about how the benighted should be treated. Treating Barnaby with dignity appealed to 
Dickens, I argue, not because of its associations with moral treatment of "the insane”, but because it accorded with his own ideas for humanitarian reform, courtesy of his belief in New Testament principles. Joseph Gold argues that "Dickens was a moralist, supported by religious faith” (276), but he was also a humanist with a strong belief in the power of ordinary people to create beneficial change for those less fortunate. For Dickens the therapeutic environment entails sufficient food and clothing, worthwhile labor, financial security, and a convivial community atmosphere, rather than coercion and self-discipline, the hallmarks of moral treatment.

Dickens held a long-standing interest in the conditions of the poor and downtrodden and visited many institutions during his career. Following the completion of Barnaby Rudge, he travelled to America where he visited schools, hospitals, prisons, and asylums. In American Notes published in1842, he details his praise for the conditions he witnessed in New England, noting with approval the provision of a knife and fork to lunatic asylum inmates in South Boston, as he felt this demonstrated the effect of "moral influence" (47) on restraining any violent tendencies. By contrast, in a later chapter of the same book, Dickens documented his horror after visiting the New York State Lunatic Asylum:

I saw nothing of that salutary system which had impressed me so favourably elsewhere; and everything had a lounging, listless, madhouse air, which was very painful. The moping idiot, cowering down with long dishevelled hair; the gibbering maniac, with his hideous laugh and pointed finger; the vacant eye, the fierce wild face, the gloomy picking of the hands and lips, and munching of the nails: there they were all, without disguise, in naked ugliness and horror. (93) Despite Dickens’s approval of the “salutary system” in Boston, none of his disabled characters are in asylums, except for the madman in Pickwick Papers. The theme of not shutting away people with mental disabilities recurs throughout his novels. For example, in 
Barnaby Rudge, the narrator enthuses, "Who would not rather see a poor idiot happy in the sunlight, than a wise man pining in a darkened jail!” (208), a sentiment echoed in David Copperfield when Betsey claims "it was one of the main joys and rewards of her life that he was free and happy, instead of pining in monotonous restraint” (909). For Smike, Barnaby, and Mr Dick, the threat of confinement is an ever-present shadow, and would have been a real threat for many people with mental impairments. In Dickens’s fiction, asylum proponents are those characters with maleficent tendencies, while opposition to asylums is demonstrated by those with whom the reader sympathizes. Salvation from a dismal existence in the asylum is rewarded by undying loyalty and gratitude from characters with mental impairment towards their middle-class protectors, with the implication that such people are best cared for in the community.

\section{Mutual reciprocity in David Copperfield}

In David Copperfield, despite having been rescued from a “dismal life” (720) in a private lunatic asylum by Betsey Trotwood's providence, the specter of the asylum hangs over the simple, benevolent Mr Dick, causing him perpetual anxiety. In this scene, Betsey explains her reasons for sheltering Mr Dick:

If it hadn't been for me, his own brother would have shut him up for life [...]

A proud fool! [...] Because his brother was a little eccentric - though he is not half so eccentric as a good many people- - he didn’t like to have him visible about his house, and sent him away to some private asylum-place: though he had been left to his particular care by their deceased father, who thought him almost a natural. And a wise man he must have been to think so! Mad himself, 
no doubt $[\ldots]$ So I stepped in [...] and made him an offer. I said, "Your brother's sane — a great deal more sane than you are, or ever will be [...] Let him have his little income, and come and live with me. I am not afraid of him, I am not proud, I am ready to take care of him, and shall not ill-treat him as some people (besides the asylum-folks) have done.” After a good deal of squabbling, I got him; and he has been here ever since. He is the most friendly and amenable creature in existence; and as for advice!—But nobody knows what that man's mind is, except myself. (260)

Once again, the middle-class benefactor demonstrates patriarchal benevolence to the simpleminded, but the character of Mr Dick is richer than a narrative trope. The perception of $\mathrm{Mr}$ Dick as a kindly, simple but mad soul is David's, and David's childhood perspective is repeatedly shown to be that of an ignorant and self-absorbed boy. If we take Betsey's perception of Mr Dick, we get a far more nuanced character. Although Betsey denies Mr Dick is a "natural", and indeed finds it foolish that anyone would think so, her fondness for him colors her perspective, and we cannot wholly trust her assertion that he is "sane." A natural was an analogous term for an idiot, or someone considered to be mentally deficient from birth. It is not certain that Mr Dick's malady stems from his birth, but being left in his brother's care when his father died suggests a long-standing mental problem, which was then exacerbated following his beloved sister’s marriage to a rogue husband.

In addition to the financial support his small income brings, Mr Dick's personal value is inestimable to Betsey, providing loyal, nonjudgmental companionship after her bitter marriage failure. Undoubtedly, Mr Dick is scatterbrained and vague at times, and Betsey constantly chides him to pay attention and use his intelligence: “don’t be a fool, because nobody can be more discreet than you can, when you choose” (248); “don’t pretend not to have a memory, because you and I know better" (248); and "how can you pretend to be wool- 
gathering, Dick, when you are as sharp as a surgeon’s lancet?” (249) But Betsey’s defence of Mr Dick's intellect is shown repeatedly to be well placed, and she takes pride in his sound advice, as proof that she is right to support him and defend him against allegations of idiocy or madness: “'Mr Dick,' said my aunt triumphantly, '[...] your common sense is invaluable’” (269). Mr Dick’s “common sense” results from his tendency to take things literally. For example, when David is dirty, Mr Dick suggests they “wash him!” (249); when David is exhausted, Mr Dick suggests they “put him to bed” (254); and as David has no clothes, Mr Dick suggests they "have him measured for a suit of clothes directly” (269).

The caring relationship between Betsey and Mr Dick is worth examining further. According to Eva Feder Kittay, the concept of care comprises three components: labor, which "requires skills on the part of the carer and uptake on the part of the cared for"; attitude, in that "good” care "denotes a positive, affective bond and investment in another's well-being"; and virtue, which entails a shift in focus from the carer's perspective to the interests of the person being cared for (52). A mutually beneficial relationship of caring depends on all three conditions being met. Similarly, Cushing and Lewis’s "philosophy of relational mutuality” envisages providing assistance to people with disabilities as a "negotiation [...] of the power imbalances structuring those relations” (174); in effect, balancing caring practices with the dignity and respect both parties deserve. Christopher Gabbard demonstrates that in Jane Eyre, Rochester's provision of care to his first wife Bertha is wholly inadequate because it fails to meet any parameters of respect and dignity for the dependent woman locked in the attic. Gabbard contrasts this with the compassionate relationship that Jane learns to cultivate as Rochester’s spouse, which, under Jane’s negotiation, becomes one of reciprocity.

Unlike the patriarchal representations of caring shown in Nicholas Nickleby and Barnaby Rudge, in which the benevolent protector assumes control over the disabled person, the relationship between Betsey and Mr Dick demonstrates mutual reciprocity of caring. 
Betsey provides Mr Dick with assistance as needed, but she does not simply take care of him. She treats him as an equal, seeks and respects his opinion, and encourages him to work. In return, she receives his friendship, devotion, and loyalty, as well as a small allowance from his family, without which she could not have provided such care. As noted above, this type of community arrangement for the person with a mental disability was not uncommon at the time Dickens was writing.

Mr Dick’s worth lies in his altruistic friendship, rather than his fiscal ability. Although David suspects that "he was only allowed to rattle his money and not to spend it" (307), this is not quite true. Mr Dick and Betsey do have "an agreement [...] that he should account to her for all his disbursements", but he restricts his spending of his own accord because he "always desired to please her” (307). When Betsey becomes destitute, Mr Dick earns a small salary as a copy clerk, an occupation David views with “disdain of the task” (104); this is not Dickens’s viewpoint. Mr Dick’s worth is more than financial to Betsey, but his monetary value should not be dismissed because it represents Dickens's belief that, with support and encouragement, people with mental disabilities could work and become useful contributors to the household economy.

\section{New models of care}

As I have discussed, in Dickens's fiction, providing for the person with a mental disability is a community responsibility. The provision of care for people with mental impairments has varied considerably over time, due in part to changing conceptualizations and classifications of disability. After the 1845 Lunatic Asylums Act made it compulsory for all counties and boroughs to erect asylums within three years, the asylum population increased dramatically. 
The proliferation of asylums made behavioral anomalies more visible, and many people, including Dickens, worried that madness was on the rise as a consequence of industrialization. Concerns of a lunacy epidemic and the best management methods became topics for debate in household magazines, as well as medical journals. Under this Act, idiots and imbeciles were included "under the medico-legal definition of 'insanity”” (Wright, “Learning,” 736) and could therefore be admitted to lunatic asylums, but most asylum superintendents were reluctant to accept them, still believing that idiocy was incurable and thus entailing a substantial long-term financial burden.

Negative attitudes toward idiots began to change in 1842 with reports of revolutionary training methods in Switzerland and Paris sparking a flood of optimism among doctors and educators alike; subsequently, idiot asylums were constructed across England, Europe and the United States in the late 1840s and 1850s. The first major British asylum for idiots opened in 1848 at Park House, Highgate, later called the Earlswood Asylum (Wright, Mental Disability). Medical articles on idiocy were published for a general audience to promote understanding and to encourage charitable donations for institutions (Dickinson). Large asylums were not the only choice for families with idiot children. From the 1840s several small private residential schools were set up by women as commercial enterprises to provide care and education to idiot children in the Bath and Bristol area (Carpenter). Not surprisingly, the quality of care provided in asylums and private schools depended on the fees that had been paid.

Two beliefs underpinned the establishment of facilities for idiot children: first, that charity toward idiots was a Christian duty (Digby), and second, that individuals were morally responsible for participating in social and economic activities to the best of their ability (McDonagh, Idiocy). Boosted by philanthropic support the idiot asylum population burgeoned in the hope that education would enable these children to become productive members of the 
community. Asylum principles accorded with the broader economic goals of increasing the productivity of the population: "superintendents assumed that educated idiots, freed from inactivity and no longer a burden to their family, would return home to be productive and upright citizens in their communities. Without education in the institution, however, the likely consequences were not promising for idiots, families or communities” (Trent 26). Wealthy families had traditionally sought private care for their idiot offspring, but after the encouraging reports from Europe many were prompted to try the new treatments offered in “purpose-built” institutions (Wright, “Family,” 191). Middle and working-class families admitted their idiot children in the hope that they would one day be able to contribute to the family economy.

Despite the enthusiasm for asylums in medical and popular periodicals, literary representations frequently criticize this model of care. And indeed confinement in asylums was not the preferred or most popular option for people with mental impairments; the majority of people regarded as idiots continued to be cared for in the community rather than asylums throughout the Victorian era (Wright, Mental Disability). Reasons for not admitting a child to an institution are difficult to gauge, as records were only kept for admissions. Speculation for why an idiot child was kept at home includes having older siblings or relatives to help manage the child, financial incapacity to pay for asylum care, and other personal decisions.

\section{Mental disability in Dickens's journalism}

Marshaling philanthropic support for asylums in journal articles was common during the 1850s, and Dickens proved no exception to this trend. Several articles on idiocy and lunacy 
appeared in his weekly periodicals, Household Words (1850-59) and All the Year Round (1860-70), drawing on the latest medical methods. Dickens did not write every piece, but he retained tight editorial control over the content of his journals and only published what he deemed suitable. For instance, despite heredity being the purported cause of Barnaby Rudge’s idiocy, Dickens appears to have later changed his mind about the subject of hereditary tainting. In 1853, he refused to have any mention of hereditary insanity in the fiction he published, rejecting Wilkie Collins’s The Monktons of Wincot Abbey for publication in Household Words. In a letter to his publishing colleague W. H. Wills (8 February 1853), he writes: "I doubt the subject of hereditary insanity [... out of] consideration for those numerous families in which there is such a taint” (Storey 23). This reluctance is surprising, given that his friend and biographer John Forster said of Dickens, “The question of hereditary transmission had a curious attraction for him, and considerations connected with it were frequently present to his mind” (636n). Why Dickens changed his mind is a mystery.

Dickens’s positive attitude to institutionalization began with his first trip to Boston in 1841 and gradually increased throughout the 1850s, but his written work reveals ambivalence. In his fiction sequestration in an asylum is never a positive option; conversely the discussion of asylums in his periodicals is mostly favorable, “only occasionally suggesting that segregation may not be the only answer” (McKnight 4). Dickens planned to visit the Park House Asylum for Idiots (later Earlswood) in September 1850, but could not attend until April 1853 due to work commitments. Following this visit he and Wills published an article titled "Idiots" in Household Words enthusing about asylum care, providing a stark contrast to his earlier fiction: "There cannot be a doubt that these Institutions are deserving of all encouragement and support. They are truly humane, and they also afford opportunities for a most interesting study which may prove exceedingly beneficial to mankind” (317). This was followed in 1854 by an article titled “Idiots Again” by Harriet Martineau claiming, "Happily, 
there are now institutions, by aiding which any of us may do something towards raising the lowest, and blessing the most afflicted [sic], members of our race” (200). The publication of these articles suggests Dickens had a change of heart regarding institutional care after he had visited Earlswood and had the chance to critique the new methods of managing mental impairment.

Dickinson argues that Dickens’s intent in writing articles “about impairment, madness and idiocy" was to increase "public understanding of these conditions" (294), which is probably true, but it is also feasible that some were commissioned by Conolly, who recognized that Dickens’s praise would be a strategic means of raising philanthropic donations for asylums. Dickens burned all his correspondence, and in his extant letters he does not directly refer to Conolly at all, so unfortunately little is known of their relationship. More surprisingly, Dickens’s extensive correspondence with Forster, a Lunacy Commissioner himself in the mid-1850s, omits to mention asylum management. Dickens’s attitude to disability in his later non-fiction rebuts the community model espoused in his earlier novels, but whether this is because he changed his mind about asylums after visiting some or whether he praised them to please his Lunacy Commissioner colleagues is difficult to determine. It is certainly worthy of consideration.

\section{Conclusion}

Literary representations of disability are useful indicators of cultural stereotypes and popular perceptions, rather than accurate portrayals of medical conditions and impairments. Despite enthusiasm for asylums in the medical literature and popular periodicals, confinement was not the preferred or most popular option for people with mental impairments, and the majority of 
people regarded as idiots continued to be cared for in the community throughout the Victorian era. Although Dickens’s journalism supports asylum care, his novels underscore the community responsibility, rather than an institutional or government one, of providing for people with mental disabilities.

\section{Works Cited}

Adair, Richard, Bill Forsythe, and Joseph Melling. “A Danger to the Public? Disposing of Pauper Lunatics in Late-Victorian and Edwardian England: Plympton St Mary Union and the Devon County Asylum, 1867-1914.” Medical History 42 (1998): 1-25. Print.

Andrews, Jonathan. "Identifying and Providing for the Mentally Disabled in Early-Modern London.” From Idiocy to Mental Deficiency: Historical Perspectives on People with Learning Disabilities. Ed. David Wright and Anne Digby. London: Routledge, 1996. 65-92. Print.

Brain, Russell. Some Reflections on Genius and Other Essays. London: Pitman Medical Publishing, 1960. Print.

Carpenter, Peter. “The role of Victorian women in the care of 'idiots' and the ‘feebleminded.'” Journal on Developmental Disabilities 8.2 (2001): 31-43. Print.

Claybaugh, Amanda. The Novel of Purpose: Literature and Social Reform in the AngloAmerican World. Ithaca and London: Cornell UP, 2007. Print.

Cornish, W.R. and Geoffrey Clark. Law and Society in England, 1750-1950. London: Sweet and Maxwell, 1989. Print. 
Cushing, Pamela and Tanya Lewis. "Negotiating Mutuality and Agency in Care-giving Relationships with Women with Intellectual Disabilities.” Hypatia 17.3 2002: 173-193. Print.

Dickens, Charles. “On Strike.” Household Words, 8.203 (1854): 553-59. Web. 12 December 2012.

---. David Copperfield. Harmondsworth: Penguin, 1985. Print.

---. Nicholas Nickleby. Melbourne: Claremont, 1999. Print.

---. American Notes and Pictures from Italy. London: Oxford UP, 1970. Print.

---. Barnaby Rudge: A Tale of the Riots of *'Eighty. London: Penguin, 2003. Print.

Dickens, Charles and W.H. Wills. “Idiots.” Household Words 7.167 (1853): 313-17. Web. 12 December 2012.

Dickinson, Hilary. “Idiocy in Nineteenth-Century Fiction Compared with Medical Perspectives of the Time.” History of Psychiatry 11.43 (2000): 291-309. Print.

Dworkin, Gerald. "Paternalism.” The Monist, 56.1 (1972): 64-84. Print.

Forster, John. The Life of Charles Dickens. Ed. J.W.T Ley, London: Cecil Palmer, 1928. Print.

Foucault, Michel. History of Madness. Ed. Jean Khalfa. Abingdon, Oxon: Routledge, 2009. Print.

Gabbard, D. Christopher. "From Custodial Care to Caring Labor: The Discourse of Who Cares in Jane Eyre.” Ed. David Bolt, Julia Miele Rodas, and Elizabeth J. Donaldson. The Madwoman and the Blindman: Jane Eyre, Discourse, Disability. Columbus: Ohio State UP, 2012. 91-110. Print.

Gleeson, Brendan. Geographies of Disability. London: Routledge, 1998. Print.

Gold, Joseph. Charles Dickens: Radical Moralist. Minneapolis: U of Minnesota P, 1972. Print. 
Holmes, Martha Stoddard. Fictions of Affliction: Physical Disability in Victorian Culture. Ann Arbor: U of Michigan P, 2009. Print.

Kittay, Eva F. “The Ethics of Care, Dependence, and Disability.” Ratio Juris 24.1 (2011): 4958. Print.

Mahendra, B. Subnormality Revisited in Early 19th Century France. Journal of Mental Deficiency Research 29.4 (1985): 391-401. Print.

Martineau, Harriet. “Idiots Again.” Household Words 9.212 (1854): 197-200. Web. 12 December 2012.

McDonagh, Patrick. “'Only an Almost’: Helen MacMurchy, Feeble Minds, and the Evidence of Literature.” Journal on Developmental Disabilities 8.2 (2001): 61-74. Print.

---. Idiocy: A Cultural History. Liverpool: Liverpool UP, 2008. Print.

McKnight, Natalie. Idiots, Madmen, and Other Prisoners in Dickens. New York: St Martin’s P, 1992. Print.

Mitchell, David T. and Sharon L. Snyder. Narrative Prosthesis: Disability and the Dependencies of Discourse. Ann Arbor: U of Michigan P, 2000. Print.

Murphy, Elaine. “The New Poor Law Guardians and the Administration of Insanity in East London, 1834-1844.” Bulletin of the History of Medicine 77.1 (2003): 45-74. Print.

Oberhelman, David D. Dickens in Bedlam: Madness and Restraint in his Fiction. Fredericton: York P, 1995. Print.

Otis, Laura, ed. Literature and Science in the Nineteenth Century: An Anthology. Oxford: Oxford UP, 2002. Print.

Priestley, Mark. “Generating Debates: Why We Need a Life Course Approach to Disability Issues.” Disabling Barriers, Enabling Environments. Ed. John Swain, Sally French, Colin Barnes and Carol Thomas. 2nd ed. London: Sage, 2004. 94-99. Print. 
Rushton, Peter. “Idiocy, the Family and the Community in Early Modern North-East England.” From Idiocy to Mental Deficiency: Historical Perspectives on People with Learning Disabilities. Ed. David Wright and Anne Digby. London: Routledge, 1996. 44-64. Print.

Simpson, Murray K. “The Moral Government of Idiots: Moral Treatment in the Work of Séguin.” History of Psychiatry 10.38 (1999): 227-43. Print.

Snyder, Sharon L. and David T. Mitchell. Cultural locations of disability. Chicago: U of Chicago P, 2006. Print.

Stainton, Tim. "Medieval charitable institutions and intellectual impairment c.1066-1600.” Journal on Developmental Disabilities 8.2 (2001): 19-29. Print.

Storey, Graham, Kathleen Tillotson, and Angus Easson, eds. The Letters of Charles Dickens. Vol VII, 1853-1855. Oxford: Clarendon P, 1993. Print.

Wright, David. "Family Strategies and the Institutional Confinement of 'Idiot' Children in Victorian England.” Journal of Family History 23.2 (1998): 190-208. Print.

---. “Learning Disability and the New Poor Law in England, 1834-1867.” Disability \& Society 15.5 (2000): 731-45. Print.

---. Mental Disability in Victorian England: The Earlswood Asylum, 1847-1901. Oxford: Clarendon, 2001. Print. 